\title{
PENERAPAN MODEL PEMBELAJARAN PAIKEM DALAM MENINGKATKAN HASIL BELAJAR SISWA MATERI SIFAT-SIFAT SIMETRI BANGUN DATAR DI KELAS V SD NEGERI 1 LABULANDA
}

\author{
Daada $^{1)}$, Muhammad Yasin ${ }^{1)}$, Yoo Eka Yana Kansi1 ${ }^{1)}$ \\ ${ }^{1)}$ Jurusan Pendidikan Guru Sekolah Dasar \\ FKIP Universitas Halu Oleo \\ email: yookansil@gmail.com
}

\begin{abstract}
Abstrak: Tujuan dari penelitian ini adalah untuk meningkatkan hasil belajar siswa pada materi sifatsifat simetri bangun datar melalui penerapan model PAIKEM di kelas V SD Negeri 1 Labulanda Kabupaten Buton Utara. Prosedur penelitian yaitu: 1) perencanaan, 2) pelaksanaan tindakan, 3) observasi dan evaluasi serta 4) refleksi. Analisis data dalam penelitian menggunakan statistik deskriptif untuk menghitung dan mendeskripsikan nilai siswa, rata-rata nilai siswa, ketuntasan belajar, keberhasilan aktivitas mengajar guru dan keberhasilan aktvitas belajar siswa. Hasil analisis penelitian menunjukkan bahwa hasil tes belajar siswa siklus I ketuntasan belajar mencapai $64 \%$ dengan rata-rata kelas 74 sedangkan pada siklus II ketuntasan belajar meningkat menjadi $92 \%$ dengan rata-rata kelas 77,4. Artinya peningkatan prestasi dari siklus I ke siklus II sebesar 28\%. Hasil observasi aktivitas belajar siswa pertemuan pertama sebesar 59,7\% dan 65,3\% pada pertemuan kedua, aktivitas mengajar guru siklus I pertemuan pertama sebesar $63,9 \%$ dan kedua sebesar $84,7 \%$. Pada siklus II aktivitas belajar siswa meningkat sebesar 91,7\% dan aktivitas guru sebesar 94,4\%. Disimpulkan bahwa penggunaan pendekatan pembelajaran PAIKEM dapat meningkatkan hasil belajar siswa materi sifatsifat simetri bangun datar di kelas V SDN 1 Labulanda.
\end{abstract}

\section{Kata kunci: Model pembelajaran, PAIKEM, hasil belajar}

\begin{abstract}
The purpose of this study is to improve student learning outcomes in the material properties of flat geometry symmetry through the application of the PAIKEM model in grade V SD Negeri 1 Labulanda, North Buton Regency. Research procedures are: 1) planning, 2) implementing actions, 3) observation and evaluation and 4) reflection. Data analysis in the study used descriptive statistics to calculate and describe student grades, average student grades, mastery learning, the success of teacher teaching activities and the success of student learning activities. The results of the analysis of the study showed that the results of the first cycle of student learning test learning completeness reached $64 \%$ with an average grade of 74 while in the second cycle the mastery learning increased to $92 \%$ with an average grade of 77.4. This means that the increase in achievement from cycle I to cycle II was $28 \%$. The results of observations of student learning activities of the first meeting amounted to $59.7 \%$ and $65.3 \%$ at the second meeting, the teaching activities of the first cycle teachers of the first meeting amounted to $63.9 \%$ and the second amounted to $84.7 \%$. In cycle II student learning activities increased by $91.7 \%$ and teacher activities by $94.4 \%$. It was concluded that the use of the PAIKEM learning approach could improve student learning outcomes in the material properties of flat geometry symmetry in class V SDN 1 Labulanda.
\end{abstract}

Keywords: Learning model, PAIKEM, learning outcomes 
Jurnal Ilmiah Pembelajaran Sekolah Dasar

Volume 1 Nomor 2 - Agustus 2019,e-ISSN 26560402

Available online at:http://ojs.uho.ac.id/index.php/jipsd

\section{Pendahuluan}

Penyebab rendahnya hasil belajar matematika siswa di sekolah disebabkan oleh penggunaan metode yang tidak tepat selama ini yang hanya menggunakan metode ceramah. Kreatifitas dan inovasi guru dalam pembelajaran masih sangat rendah. Pembelajaran cenderung berlangsung dengan membosankan yang membuat siswa menjadi jenuh dan kurang tertarik dalam mengikuti proses pembelajaran. Dalam pembelajaran guru tidak menggunakan media sebagai alat untuk membuat siswa lebih memahami materi pelajaran. Hal ini terlihat dari nilai siswa hasil ulangan semester genap tahun pelajaran 2015/2016 pada materi sifat-sifat simetri bangun datar. Secara klasikal, dari 25 orang siswa hanya 15 orang atau $60 \%$ yang mencapai ketuntasan hasil belajar dan 10 orang siswa atau $40 \%$ yang tidak mencapai ketuntasan hasil belajar. Hasil belajar siswa tersebut belum mencapai nilai KKM yang ditetapkan di sekolah untuk mata pelajaran matematika yaitu 65 .

Berdasarkan hasil observasi dapat ditengarai bahwa aspek proses dan hasil pembelajaran merupakan salah satu penyebab perlunya ditingkatkan mutu pendidikan. Kualitas proses dan hasil belajar mengajar yang rendah menunjukkan bahwa interaksi antara siswa dengan sumber belajar seperti dengan guru dan lingkungan, tidak berjalan efektif sehingga hasil belajar yang dicapai tidak optimal. Oleh karena itu dalam proses pembelajaran diupayakan agar lingkungan belajar dapat mendukung berlangsungnya pembelajaran efektif dan berpusat pada siswa.

Upaya meningkatkan hasil belajar siswa merupakan salah satu tugas dan tanggungjawab seorang guru atau tenaga pendidik. Salah satu upaya untuk meningkatkan kualitas pengajaran seorang guru adalah memperbaiki pola pembelajaran dengan menerapkan pendekatan atau model belajar yang dinilai efektif dan efisien oleh guru untuk diterapkan di kelas. Untuk itu perlu dicari pemecahan masalah dalam menentukan strategi pembelajaran yang tepat, dengan tetap mempertimbangkan kondisi-kondisi dalam kelas. Semuanya dimaksudkan untuk memperoleh pendekatan pembelajaran yang tepat bagi seluruh siswa. Oleh karena itu, peneliti bermaksud mengadakan upaya perbaikan pembelajaran di kelas dengan menerapkan pendekatan pembelajaran yang bersifat aktif, inovatif, kreatif, efektif dan menyenangkan (PAIKEM).

Berdasarkan latar belakang di atas, maka penulis tertarik untuk melakukan penelitian dengan judul "Penerapan Model PAIKEM dalam Meningkatkan Hasil Belajar Siswa Materi Sifat-Sifat Simetri Bangun Datar di Kelas V SD Negeri 1 Labulanda Kabupaten Buton Utara".

Hasil penelitian yang dilakukan Asfiani (2012) yang menyimpulkan bahwa melalui pendekatan PAIKEM pada materi jaring-jaring bangun ruang dapat meningkatkan hasil belajar siswa di kelas IV SD Negeri 2 Tuangila. Hasil penelitian berupa rata-rata hasil belajar siswa pada siklus I yaitu 67,64 menjadi 77,12 pada siklus II. Selain itu terjadi peningkatan jumlah siswa yang tuntas belajarnya pada siklus I adalah 17 atau 44,74\% dari jumlah keseluruhan siswa yakni 38 siswa meningkat menjadi 35 siswa atau $92,11 \%$ pada siklus II.

Hasil penelitian yang dilakukan oleh $\mathrm{Hj}$. Nurhayati (2012) yang menyimpulkan bahwa pendekatan PAIKEM dapat meningkatkan hasil belajar siswa kelas I SDN 16 Kendari Barat pada penjumlahan dan pengurangan bilangan. Hasil belajar siswa siklus I yang tuntas sebanyak 12 orang $(44,44 \%)$ sedangkan pada siklus II yang tuntas sebanyak 24 orang $(88,89 \%)$.

Model pembelajaran PAIKEM dirancang secara matang dan dilaksanakan secara tepat diharapkan dapat mendorong siswa lebih dapat meningkatkan persiapan dalam menerima pelajaran. Peningkatan motivasi belajar siswa juga diharapkan membawa dampak positif yaitu peningkatan hasil belajar siswa.

Masalah dalam penelitian adalah apakah penerapan model PAIKEM dapat meningkatkan hasil belajar siswa pada materi sifat-sifat simetri bangun datar di kelas V SD Negeri 1 Labulanda Kabupaten Buton Utara?. Tujuan penelitian adalah untuk meningkatkan hasil belajar siswa pada materi sifat-sifat simetri bangun datar melalui penerapan model PAIKEM di kelas V SD Negeri 1 Labulanda Kabupaten Buton Utara. Penelitian ini diharapkan dapat memberikan manfaat bagi guru, siswa, sekolah dan penelitian lainnya. 


\section{Metode Penelitian}

Jenis penelitian ini adalah penelitian tindakan kelas (PTK) (Kurniasih dan Sani, 2014:3).. Penelitian ini telah dilaksanakan pada semester genap tahun pelajaran 2016/2017 bertempat di kelas V SD Negeri 1 Labulanda yang terletak di Desa Langkumbe Kecamatan Kulisusu Barat Kabupaten Buton Utara. Subjek penelitian ini adalah siswa kelas V SD Negeri 1 Labulanda Kabupaten Buton Utara yang berjumlah 25 orang terdiri dari 11 orang siswa perempuan dan 14 orang laki-laki. Faktor yang diteliti adalah aktivitas mengajar guru dan faktor siswa. Penelitian tindakan kelas ini dilaksanakan dalam dua siklus yang terdiri dari empat tahapan yaitu perencanaan, pelaksanaan tindakan, observasi dan evaluasi serta refleksi. Jenis data dalam penelitian ini adalah 1) data kualitatif yaitu fakta-fakta yang ditemukan disaat guru mengajarkan Sifat-sifat simetri bangun datar menggunakan model PAIKEM dan data kuantitatif yaitu data berupa angka-angka atau nilai hasil belajar siswa seperti rata-rata hasil belajar dan persentase ketuntasan hasil belajar siswa.

Analisis data dalam penelitian ini adalah menggunakan statistik deskriptif untuk menghitung dan mendeskripsikan nilai siswa, rata-rata nilai siswa, ketuntasan belajar, keberhasilan aktivitas mengajar guru dan keberhasilan aktivitas belajar siswa.

1. Menentukan Nilai Siswa

Nilai siswa ditentukan berdasarkan skor yang diperoleh siswa pada tes yang dilakukan dengan rumus:

$$
\text { Nilai Siswa }=\frac{\text { SkorPerolehan Siswa }}{\text { Skor Maksimum }} \times 100 \quad \text { (Suparno, 2008: 80) }
$$

2. Menentukan Rata-Rata Nilai Siswa

$$
\text { Nilai rata }- \text { rata }(X)=\frac{\text { jumlah nilai seluruh siswa }}{\text { jumlah siswa }} \quad \text { (Suparno, 2008: 81) }
$$

3. Menentukan ketuntasan belajar

a. Ketuntasan Individu

Ketuntasan individu siswa ditentukan berdasarkan nilai yang diperoleh pada setiap siklus. Siswa dikatakan belajar tuntas jika nilai yang diperoleh siswa adalah $\geq 65$ sesuai KKM yang ditetapkan sekolah.

b. Ketuntasan Klasikal

Ketuntasan klasikal ditentukan berdasarkan persentase ketuntasan individu siswa pada setiap siklus pembelajaran dengan rumus sebagai berikut.

Persentase ketuntasan $=\frac{\text { jumlah siswa tuntas }}{\text { jumlah seluruh siswa }} \times 100 \% \quad$ (Suparno, 2008: 82)

Ketuntasan klasikal tercapai jika minimal 70\% siswa telah mencapai ketuntasan individual.

c. Menentukan Keberhasilan Aktivitas Mengajar Guru

Untuk menentukan Keberhasilan Aktivitas Mengajar Guru (KAMG) dapat dilihat pada keterlaksanaan skenario pembelajaran. Persentase keterlaksanaan skenario pembelajaran dihitung berdasarkan jumlah skor perolehan guru dibagi jumlah skor maksimum dikalikan dengan seratus persen.

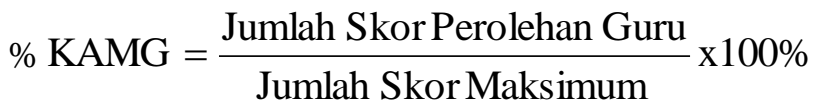

$$
\begin{array}{ll}
\mathrm{K} & =\text { Keberhasilan } \\
\mathrm{A} & =\text { Aktivitas } \\
\mathrm{M} & =\text { Mengajar } \\
\mathrm{G} & =\text { Guru }
\end{array}
$$

(Suparno, 2008: 83) 
d. Menentukan Keberhasilan Aktivitas Belajar Siswa

Keberhasilan aktivitas belajar siswa (KABS) dihitung berdasarkan skor perolehan siswa dibagi jumlah skor maksimum dikalikan dengan seratus persen.

$$
\begin{aligned}
\% \text { KABS } & =\frac{\text { Jumlah Skor Perolehan Sis wa }}{\text { Jumlah Skor Maksimum }} \times 100 \% \\
\mathrm{~K} & =\text { Keberhasilan } \\
\mathrm{A} & =\text { Aktivitas } \\
\mathrm{B} & =\text { Belajar } \\
\mathrm{S} & =\text { Siswa }
\end{aligned}
$$

(Suparno, 2008: 84)

Indikator keberhasilan tindakan pembelajaran dalam penelitian ini adalah 1) Proses pembelajaran dikatakan berhasil jika persentase keberhasilan aktivitas mengajar guru dan persentase keberhasilan aktivitas belajar siswa mencapai $\geq 80 \%$ pembelajaran terlaksana dengan sesuai dengan RPP (Kurniasih dan Sani, 2013:33), 2) Ketuntasan belajar siswa tercapai jika minimal $70 \%$ siswa memperoleh nilai $\geq 65$ sesuai KKM yang ditetapkan sekolah (Ketetapan KKM mata pelajaran Matematika di sekolah).

\section{Hasil Penelitian \\ Hasil Belajar Siswa}

Hasil tes belajar siswa siklus I ketuntasan belajar mencapai $64 \%$ dengan rata-rata kelas 74 sedangkan pada siklus II ketuntasan belajar meningkat menjadi 92\% dengan rata-rata kelas 77,4. Artinya peningkatan prestasi dari siklus I ke siklus II sebesar $28 \%$.

\section{Aktivitas Mengajar Guru}

keberhasilan aktivitas mengajar guru siklus I pertemuan pertama sebesar $63,9 \%$ dan kedua sebesar $84,7 \%$. Pada siklus II aktivitas guru sebesar 94,4\%.

\section{Aktivitas Belajar Siswa}

Hasil observasi aktivitas belajar siswa pertemuan pertama sebesar 59,7\% dan 65,3\% pada pertemuan kedua. Pada siklus II aktivitas belajar siswa meningkat sebesar 91,7\%.

\section{Pembahasan}

\section{Hasil Belajar Siswa}

Hasil belajar diperoleh melalui evaluasi atau penilaian dengan tujuan untuk mengukur tingkat penguasaan siswa. Evaluasi atau tes yang diberikan setelah pembelajaran usai. Hal ini sejalan dengan pendapat Abdurrahman dalam Jihad (2010, 9:18) menyatakan "hasil belajar adalah kemampuan yang diperoleh anak setelah melalui kegiatan belajar". Sedangkan menurut Juliah dalam Jihad (2010, 9:15) menyatakan "hasil belajar adalah segala sesuatu yang menjadi milik siswa sebagai akibat dari kegiatan belajar yang dilakukannya".

Perbandingan ketunasan belajar siswa pada siklus I dan siklus II dapat dilihat pada tabel 4.7. berikut:

Tabel 1. Ketuntasan Hasil Belajar Siswa Secara Klasikal Setiap Siklus

\begin{tabular}{lcccc}
\hline \multirow{2}{*}{ No. } & \multirow{2}{*}{ Siklus } & Hasil Belajar & Jumlah Siswa & Presentase \\
\hline 1. & \multirow{2}{*}{ I } & Tuntas & 16 & 64 \\
\cline { 3 - 5 } & \multirow{2}{*}{ II } & Tidak Tuntas & 9 & 36 \\
\cline { 3 - 5 } & & Tuntas & 23 & 92 \\
\hline
\end{tabular}

Berdasarkan hasil penelitian yang telah dilakukan menunjukkan bahwa dengan menerapkan model pembelajaran PAIKEM dalam pembelajaran memiliki dampak positif dalam meningkatkan hasil belajar matematika siswa pada materi sifat-sifat simetri bangun datar di kelas V SD Negeri 1 
Jurnal Ilmiah Pembelajaran Sekolah Dasar

Volume 1 Nomor 2 - Agustus 2019,e-ISSN 26560402

Available online at:http://ojs.uho.ac.id/index.php/jipsd

Labulanda. Hal ini dapat dilihat dari adanya peningkatan hasil belajar siswa pada setiap siklus. Ratarata hasil tes siklus I adalah 74 dengan presentase ketuntasan 64\%. Namun nilai tersebut belum mencapai standar indikator yang telah ditentukan. Kemudian pada siklus II, rata-rata hasil tes siklus II adalah 77,4 dengan presentase ketuntasan 92\%. Hal tersebut menunjukkan bahwa hasil belajar siswa telah mencapai indikator yang telah ditetapkan yaitu $70 \%$ siswa telah memperoleh nilai $\geq 65$.

\section{Aktivitas Mengajar Guru}

Analisis hasil observasi kegiatan siswa dalam pembelajaran menunjukkan bahwa pembelajaran dengan penerapan model pembelajaran PAIKEM memiliki dampak positif dalam meningkatkan kualitas kegiatan guru. Hal ini terlihat dari hasil observasi kegiatan guru pada setiap pertemuan. Pada siklus I, persentase kegiatan mengajar guru yaitu $63,9 \%$ pada pertemuan pertama dan meningkat menjadi $84,7 \%$ pada pertemuan kedua. Namun disadari masih terdapat kekurangan-kekurangn yang masih perlu diperbaiki, diantaranya: (1) guru menyampaikan materi pelajaran kurang sistematis dan agak cepat, (2) guru tidak membimbing semua siswa yang mengalami kesulitan, (5) guru tidak meminta siswa menanyakan materi pelajaran yang belum dimengerti, (4) guru tidak melibatkan siswa dalam membuat kesimpulan materi pelajaran.

Berdasarkan kekurangan yang ada pada siklus I maka pada siklus II peneliti lebih menitikberatkan perbaikan kekurangan tersebut agar pembelajaran berjalan lancar dan efektif. Guru telah memperbaiki cara menyampaikan konsep materi pembelajaran sehingga merangsang daya nalar dan motivasi siswa untuk belajar lebih baik. Pada siklus II pertemuan pertama persentase aktivitas guru mencapai $93,1 \%$ dan pertemuan $100 \%$. Seperti yang dikemukakan oleh Sanjaya (2005: 176) bahwa memberikan komentar/penjelasan yang baik terhadap materi pelajaran yang akan dipelajari dapat menggugah perhatian siswa sehingga dapat membangun suasana pembelajaran yang optimal. Pendapat tersebut juga serupa dengan yang dikemukakan oleh Syah (2010: 23) bahwa untuk memotivasi siswa maka guru harus mampu menarik perhatian/ mempertahankan perhatian siswa dan mengusahakan agar siswa mau mempelajari materi-materi yang diharapkan untuk dipelajari.

\section{Aktivitas Belajar Siswa}

Pada penelitian ini, siswa dibagi dalam kelompok yang dilakukan dengan mempertimbangkan perbedaan kemampuan serta jenis kelamin. Hal ini sejalan dengan salah satu ciri model pembelajaran kooperatif yang dikemukakan oleh Arends (dalam Trianto 2010:65) menyatakan bahwa kelompok dibentuk dari siswa yang mempunyai kemampuan tinggi, sedang, dan rendah serta bila memungkinkan anggota kelompok berasal dari ras, budaya, suku dan jenis kelamin yang beragam. Analisis hasil observasi kegiatan siswa dalam pembelajaran menunjukkan bahwa pembelajaran dengan penerapan pendekatan pembelajaran PAIKEM memiliki dampak positif dalam meningkatkan hasil belajar siswa. Hal ini dapat dilihat dari hasil observasi kegiatan belajar siswa dari setiap pertemuan ke pertemuan selanjutnya.

Berdasarkan hasil observasi pada siklus I, kegiatan belajar siswa belum terlaksana dengan baik dan masih terdapat kekurangan-kekurangan yang harus diperbaiki. Hal ini terlihat dari hasil observasi yang dilakukan yang menunjukkan masih ada hal-hal belum sepenuhnya terlaksana secara maksimal diantaranya: (1) tidak semua siswa memberikan jawaban terhadap apersepsi dan motivasi yang dilakukan guru, (2) tidak semua siswa mendengarkan penjelasan guru tentang tujuan pembelajaran, (5) tidak semua siswa memperhatikan penjelasan materi dari guru, (4) tidak semua siswa mengerjakan LKS secara berkelompok, (5) tidak semua siswa dapat berkomunikasi secara baik dengan kelompoknya, (6) masih ada beberapa siswa yang takut maju ke depan kelas untuk menuliskan hasil jawabannya, (7) belum semua siswa memperhatikan penjelasan guru tentang jawaban yang masih salah, (8) siswa masih banyak yang belum berani mengemukakan kesulitannya, (9) siswa kurang dilibatkan dalam membuat kesimpulan pelajaran.

Hasil observasi aktivitas siswa selama pelaksanaan tindakan siklus I masih rendah. Pertemuan pertama persentase aktivitas siswa mencapai $59,7 \%$ dan pertemuan kedua mencapai $65,3 \%$. Berdasarkan 
kekurangan-kekurangan tersebut, maka penelitian dilanjutkan pada siklus II. Pada siklus II siswa sudah dapat mengikuti pembelajaran dengan lebih baik, hal tersebut dapat dilihat dari meningkatnya hasil observasi siswa pada tindakan siklus II. Pertemuan pertama persentase aktivitas siswa mencapai 93,1\% dan pertemuan kedua mencapai 98,6\%. Hal ini sejalan dengan pendapat Ambo, Yasin, \& Ili. (2019) proses belajar di mana guru harus menciptakan situasi belajar yang problematis, menstimulus siswa dengan pertanyaanpertanyaan, mendorong siswa mencari jawaban sendiri. Bentuk lain dari belajar penemuan adalah guru menyajikan contoh-contoh dan siswa bekerja dengan contoh tersebut sampai dapat menemukan sendiri hubungan antarkonsep.

\section{Simpulan}

1. Penggunaan model pembelajaran PAIKEM dapat meningkatkan hasil belajar Matematika materi sifat-sifat simetri bangun datar pada siswa kelas V SD Negeri 1 Labulanda.

2. Berdasarkan hasil observasi pada siklus I dan siklus II persentase aktivitas siswa dalam mengikuti pembelajaran PAIKEM selalu meningkat, ini dapat dilihat dari pencapaian indikator.

3. Berdasarkan hasil observasi pada siklus I dan siklus II persentase aktivitas guru dalam melaksanakan pembelajaran PAIKEM selalu meningkat, ini dapat dilihat dari pencapaian indikator penelitian.

\section{Daftar Pustaka}

Ambo, W. A. W., \& Yasin, M. (2019). Meningkatkan Hasil Belajar Matematika Siswa Pada Materi Persegi Dan Persegi Panjang Melalui Penerapan Metode Discovery Learning Di Kelas Iii Sd Negeri 2 Barangka. Jurnal Ilmiah Pembelajaran Sekolah Dasar (JIPSD), 1(1).

Asfiani. 2012. Meningkatkan Hasil Belajar Siswa pada Materi Jaring-Jaring Bangun Ruang Melalui Pendekatan PAIKEM di Kelas IV SD Negeri 2 Tuangila. Skripsi. Kendari: FKIP Unhalu.

Jihad A. dan Haris A., 2010. Evaluasi pembelajaran. Yogyakarta: Multi Pressindo.

Kurniasih dan Sani, 2013. Teknik dan Cara Mudah Membuat Penelitian Tindakan Kelas Untuk pengembangan Profesi Guru. Jakarta: Katapena

Nurhayati. 2012. Meningkatkan Hasil Belajar Siswa pada Materi Penjumlahan dan Pengurangan Melalui Model PAIKEM di Kelas I SDN 16 Kendari Barat. Skripsi. Kendari: FKIP. Unhalu.

Sanjaya W. 2005. Perencanaan dan Desain Sistem Pembelajaran. Jakarta: Kencana.

Suparno, Paul. 2008. Riset Tindakan untuk Pendidik. Jakarta: Grasindo.

Syah M. 2010. Pisikologi Pendidikan Dengan Pendekatan Baru. Bandung: Remaja Ros Dakarya.

Trianto, 2010. Mendesain Model Pembelajaran Inovatif-Progresif. Surabaya: Kharisma Putra Utama. 